\title{
A.3 Asiatic Society of Bengal, Kolkata, Ms. B $5^{3}$
}

\author{
An "old" Nepalese paper manuscript of 171 folios. ${ }^{4}$
}

1. Halāhala-hṛdaya

2. Abhayaṃkarī [72]

3. Sahasrāvartā [68]

4. Siṃhanāda [64]

5. Șaḍakṣarī-mahāvidyā [69]

6. Avalokiteśvara-siddhinikā [65]

7. Avalokiteśvara-nīlakaṇțha [67]

8. Amoghapāśa [63]

9. Tārā

10. Cundā [75]

11. Mokșapada [71]

12. Cundābhațțārikā-rakṣā [110]

13. Sarvalokeśvarā [121]

14. Mañjuśrīpratijñā [58]

15. Mañjuśrī-sādhana [123]

16. Maitreya [124]

17. Saddharmapāṭha [125]

18. Vajratārā [126]

19. Aparimitāyur [47]

20. Sarvadurgati [45]

21. Vasuṃdharā

22. Vajravidāraṇa [98]

23. Gaṇapati-hṛdaya [99]

24. Uṣnịisavijayā [100]

25. Mārīcī [102]

3 After Mitra 1882: 292. I have not been able to consult the original manuscript or any reproductions. Titles given with minor standardizations. Corresponding text numbers in Cambridge Ms. Add. 1326 are given in square brackets (there is a chance of inconsistencies in the case of texts which appear by the same title more than once).

4 Mitra 1882: 80. While this manuscript is described in Mitra 1882: 80-81, 291-292, Shastri 1917 does not include this witness, only a Saptavāra manuscript of 33 leaves listed as Dhāraṇisaṃgraha on page vii and as "a number of Dhāraṇīs with illustrations" on page 48. Note that Hunter 1881: 19 reports on a Dhāraṇisamgraha manuscript given as no. 21 in a "[1]ist of 66 Sanskrit Buddhist works obtained from the Library of the College of Fort William, and forwarded thereto by B.H. Hodgson, Esq., from Nepal.” 
26. Parṇaśavarī [85]

27. Grahamātṛkā [103]

28. Dhvajāgrakeyūrā [90]

29. Pratisarā [76]

30. Pratisarā [77]

31. Mahāsāhasrapramardanī [78]

32. Mahāmāyūrī [79]

33. Sìtavatī-mahāvidyā [80]

34. Mahārakṣā-mantrānusāriṇī [81]

35. Pañcaviṃśatikā-prajñāpāramitā-hṛdaya [101]

36. Hemagāthā

37. Mahāmāyāvijayavāhinī-nārāyaṇapṛcchā [91]

38. Lan̉kāvatāra [12]

39. Vasuṃdharāvrata-pūrvamūrtya-maṇḍala 